\title{
THE RELATION OF PATENTS TO THE ANTITRUST LAWS
}

\author{
Grorge E. FolK*
}

Is there a clash of principles between the United States patent system, which grants an unconditional monopoly of an invention, and the system of free competitive enterprise, which it is a policy of the antitrust laws to uphold? I believe there is not.

There should be no special difficulty in reconciling our patent laws with our antitrust laws. The courts have readily defined their respective spheres by "recognizing the nature of the property dealt in." While private ownership of property, including patent property, is essentially a limitation of the activities of others, it is also true that under our system of free enterprise private ownership and complete control of the property involved not only promote free enterprise but are essential to it.

It is not the ownership or control of property-the monopoly thereof-whether it be patents or other property rights, that the antitrust laws are aimed at, but at abuses of those rights. Free enterprise does not mean that anyone should be free to conduct an enterprise with another's property without the other's permission.

Whenever a person enters into a contract which covers something beyond the rights inherent in the patent grant, the transaction, of course, is subject to the general law and the patent affords no immunity.

\section{The Objectives of the Antitrust Act}

The Sherman Antitrust Law was enacted in $1890^{2}$ and has for its objective a curb, beyond that of the common law, upon monopolies resulting in unreasonable restraint of interstate and foreign trade. The ownership and control of any kind of property is a monopoly of that property, whether it be real estate or personal property -whether, for example, it be the ownership of lands resulting from land grants by the Government or whether it be patentable inventions covered by a patent.

* A.B. 1889 , Newberry College; A.B. 1893 , A.M. 1894 , Yale University. Member of District of Columbia, Illinois, and New York bars. General practice of patent law in Chicago for ten years. General Patent Attorney for American Telephone \& Telegraph Company for twenty-two years until retirement. Since then, for the last ten years, Patent Advisor to National Association of Manufacturers. Author, Patents and Industrial Progress (1942); Patents and the Anti-Trust Laws (1942); Fundamentals of the U. S. Patent System (r943); A Review of Proposals for the Revision of the U. S. Patent System (i946); Review of tFe Supreme Court's Decistons in the Line Material Case and t7ie U. S. Gypsum Company Case (1948); and various other monographs.

${ }^{1}$ Bement v. National Harrow Co., I 86 U. S. 70 (I902); United States v. General Electric Co., 272 U. S. 476 (1926).

26 STAT. 209 (1890), as amended, 15 U. S. C. $\$ 5 \mathrm{I}-7$ (1940). 


\section{Objectives of the Patent Laws}

In the Constitution our forefathers provided for the development of our geographical frontiers by providing that "the Congress shall have power to dispose of and make all needful rules and regulations respecting the territory or other property belonging to the United States ..."3 Exercising this power, Congress passed laws by which land patents were granted. ${ }^{4}$ Such a land patent vested title to the land in perpetuity in the grantee. At the same time, in order to encourage the discovery and development of scientific frontiers, our forefathers provided in the Constitution that Congress should have power to "promote the progress of science and useful arts, by securing for limited times to . . . inventors the exclusive right to their . . . discoveries."

Thus a land patent grants a property right (a monopoly) in perpetuity, while a patent for an invention grants a property right (a monopoly) for a limited time only -at first for fourteen, now for seventeen years.

The Supreme Court has repeatedly held, to quote the exact words in one instance, that "a patent for an invention is as much property as a patent for land. The right rests upon the same foundation, and is surrounded and protected by the same sanctions."

A patent, therefore, is a monopoly in the same sense that the ownership and control of any property is a monopoly. There was no occasion in the antitrust laws to specify patents as an exception to the application of those laws. There is no reason for assuming that patents are an exception. However, at times the courts have made such statements as: ". . . a patent is an exception to the general rule against monopolies and to the right to access to a free and open market."7

\section{The "Rule of Reason"}

Obviously, a literal application of the language of the Sherman Act would seriously hamper interstate and foreign trade. Therefore, the Supreme Court has applied "the rule of reason" in interpreting the statute; i.e., it inquires whether the restraint of trade is reasonable or unreasonable. Even before the rule of reason was used as a guide, the Supreme Court had held that the Sherman Act "clearly does not refer to that kind of restraint of interstate commerce which may arise from reasonable and legal conditions imposed upon the assignee or licensee of a patent by the owner thereof, restricting the terms upon which the article may be used and the price to be demanded therefor." 8

${ }^{3}$ U. S. Const. Art. IV, $\$_{3}(2)$.

4 Rev. Stat. $\$ 453$ (1875), 43 U. S. C. \$2 (I940).

EU. S. Const. Art. I, $\$ 8(8)$.

'Consolidated Fruit Jar Co. v. Wright, 94 U. S. 92, 96 (1876). See also James v. Campbell, I04 U. S. 356 (188I); United States v. Dubilier Condenser Corp., 289 U. S. I78 (1933); and Hartford-Empire Co. v. United States, 323 U. S. 386 (x945).

${ }^{7}$ Precision Instrument Mfg. Co. v. Automotive Maintenance Machinery Co., 324 U. S. 806, 816 (I945).

${ }^{B}$ Bement v. National Harrow Co., stupra note I, at 92. 
In an able early decision of one of our federal district courts it was stated that "it seems self-evident that a contract which is only co-extensive with the monopoly conferred by letters patent and which creates no additional restraint of trade or monopoly, does not conflict with the Sherman Act."'

It becomes important, therefore, to understand fully the nature of the patent grant and what is inherent in that grant.

In the half century that has elapsed since the passage of the Sherman Act, we have decisions from our courts on patent agreements covering almost every conceivable state of facts. While there is no rule of thumb to apply, and while borderline cases arise which may cause one person in good faith to conclude that a particular patent agreement is legal and another person to conclude that it is illegal, there are still definite answers to most questions that are likely to arise.

The following statement of the United States Supreme Court sets down the rule about as definitely as it can be stated: ". . . the rule is, with few exceptions, that any conditions which are not in their very nature illegal with regard to this kind of property, imposed by the patentee and agreed to by the licensee for the right to manufacture or use or sell the article, will be upheld by the courts."10 This was preceded by a statement that "the very object of these [patent] laws is monopoly, ..."11 In the same case, the Court called attention to the necessity of ". . . recognizing the nature of the property dealt in ..."12 The failure to do so will result in confusion.

Let us therefore examine into the nature of the patent property and list the more common rights and wrongs with respect thereto that have been determined.

\section{Nature of the Patent Grant}

In the course of the last century our courts have at frequent intervals emphasized the fundamental nature of the patent grant. They have not expressed any difference of opinion on this subject, not even in the more recent Supreme Court decisions.

The right which the patent confers 'consists solely in the right to exclude everyone except the patent owner from making, using, or vending the thing patented without permission of the patentee. That is all that the patent confers. Any right that the patentee himself may have to make, use, or sell his invention is a commonlaw right.

It is obvious that an inventor, whether or not he is granted a patent, has a right in his own invention or discovery. That is, he has a common-law right in his mental creation. At common law, however, he had no exclusive right, and the only way in which he could prevent the appropriation of his discovery by others was to conceal it. The patent supplements this common-law right by granting to the patentee the right to exclude others from making, using, or vending the invention.

\footnotetext{
' Blount Mfg. Co. v. Yale \& Towne Mfg Co., x66 Fed. 555, 557 (D. Mass. 1909).

${ }^{10}$ Bement v. National Harrow Co., supra note 1 , at 91 .

11 7bid.

${ }^{19} I d$. at 93 .
} 
That is what the Constitution means when it gives Congress the power to secure to the inventor the exclusive right to his discovery-that is, the right to exclude others for a limited period.

\section{Erroneous Views Expressed by the Antitrust Division of the Department of Justice}

The views just expressed regarding the nature and scope of the patent monopoly have not in recent years been willingly accepted by the United States Department of Justice. Repeated prior rulings of the Supreme Court have been absolutely ignored; and we find representatives of the Antitrust Division, in arguments before the Supreme Court, in testimony given before congressional committees, and in statements made before government investigating committees, expressing views as to what the law is directly contrary to the accepted views. For example, compare such statements of the Supreme Court as that

a patent for an invention is as much property as a patent for land. The right rests on the same foundation, and is surrounded and protected by the same sanctions, ${ }^{13}$

with statements emanating from the Department of Justice, such, for example, as:

There may be some doubt, hqwever, whether patents are the kind of "property" included within the constitutional requirement for just compensation; ${ }^{14}$

and also,

I mean there may be some question at to whether the taking of a patent is the taking of property within the meaning of the Constitution. ${ }^{15}$

And again, the same spokesman raises the question whether a patent is "a property right, or something that may be withdrawn."16

We also find the Antitrust Division urging, in a brief field by the Department of Justice as amicus curiae in the Talking Pictures case, ${ }^{17}$ the novel theory that:

If a patent grant is limited to its proper orbit ... the scope of the rights of the patentee will be the legal permission to make, use and vend given by the statute to implement the constitutional provisions...

In the simpler economy in which the notion of the patent was born, the usual patent monopoly was nothing more than the exclusive right to produce for a limited period of years...

But if the rights of the patent owners are allowed to be extended beyond the privilege to make, use and vend, the whole matter becomes confused...

The controlling principle is that the patent privilege does not go beyond the privilege "to make, use and vend."18

${ }^{15}$ See note 6 supra.

${ }^{16}$ Hearings before the Senate Committee on Patents on S. 2303, 77th Cong., $2 \mathrm{~d}$ Sess. 36 (1942).

${ }^{15} \mathrm{Id}$. at 34 .

${ }^{10} \mathrm{Tbid}$.

${ }^{17}$ General Talking Pictures Corp. v. Western Electric Co., 305 U. S. 124 (1938).

${ }^{18}$ In a brief filed by the Department of Justice as amicus curiae in General Talking Pictures Corp. v. Western Electric Co., supra note I7. 
Furthermore, in testimony before the Senate Committee on Patents of the Seventy-seventh Congress, a statement was made on behalf of the Antitrust Division calculated to leave the impression that in the early days the inaccurate and unsubstantiated views quoted above expressed the correct basic principles, from which the Supreme Court later incorrectly strayed. For example, we have a statement from the Antitrust Division as follows:

The first patent law interpreted "exclusive right" to mean an exclusive right to produce or use the invention. . . ${ }^{19}$ This meant giving a monopoly of production for a limited time.

No authority was or can be cited in support of such statement.

Thus we find advanced by those in responsible positions in the Department of Justice certain astounding and revolutionary views regarding patents. These erroneous views are, in the main: (I) that a patent merely grants to the inventor "permission" to make, use, and sell the new thing invented by him; (2) that the grant of any limited form of license, incorrectly called a "restrictive" license, is outside any right inherent in a patent; and (3) that patents do not represent property rights such as the United States Constitution undertakes to protect. These are concepts wholly different from those that have from the very first universally prevailed, up to and including the most recent pronouncements of the Supreme Court.

These erroneous views have been set forth because they are essential to an understanding of why the Supreme Court has taken such pains to reassert at some length in recent decisions the nature and scope of the patent monopoly, and especially the rights which the patentee has in general with reference to the grant of limited, or so-called "restrictive," licenses.

\section{License Restrictions in General}

The inherent right to specify certain restrictions in patent licenses was early recognized by the courts. The Supreme Court said in Gayler v. Wilder:

The monopoly did not exist at common law, and the rights, therefore, which may be exercised under it cannot be regulated by the rules of the common law. ${ }^{20}$

A leading case involving license restrictions is Bement v. National Harrow Company, in which is found the following statement:

... the general rule is absolute freedom in the use or sale of rights under the patent laws of the United States. The very object of those laws is monopoly, and the rule is, with few exceptions, that any conditions which are not in their very nature illegal with regard to this kind of property, imposed by the patentee and agreed to by the licensee for the right to manufacture or use or sell the article, will be upheld by the courts. ${ }^{21}$

In the same case, the Court further stated, referring to the Sherman Antitrust Act, that it

\footnotetext{
${ }^{10}$ Hearings, supra note 14 , at 627 .

${ }^{20}$ Io How. 477,494 (U. S. 1850).

${ }^{21}$ I86 U. S. 70,91 (1902).
} 
... clearly does not refer to that kind of a restraint of interstate commerce which may arise from reasonable and legal conditions imposed upon the assignee or licensee of a patent by the owner thereof, restricting the terms upon which the article may be used and the price to be demanded therefor. ${ }^{22}$

Another case of interest, because it was the first in which the Supreme Court was called on to consider the above-mentioned arguments of the Government, is General Talking Pictures Corporation v. Western Electric Company.23 In that case, after the Supreme Court had made its decision, the Government asked permission to intervene as amicus curiae upon rehearing. Permission was granted. The Court, speaking through Mr. Justice Brandeis, said:

That a restrictive license is legal seems clear. .. . As was said in United States v. General Electric Company, 272 U. S. 476,489 , the patentee may grant a license "upon any condition the performance of which is reasonably within the reward which the patentee by grant of the patent is entitled to secure. ..." The practice of granting licenses for a restrictive use is an old one ... So far as appears, its legality has never been questioned. ${ }^{24}$

Similarly, in more recent decisions, down to the current ones, we find the Supreme Court in agreement upon such statements of the law, as will be seen by subsequent reference to those decisions. There seems to have been no question in the minds of the justices as to the established law and its application to the facts, though the Court split on the question of the remedy that should be applied where violations of the law were found to exist.

\section{Restrictions Within the Scope of the Patent Grant}

There are a number of restrictions or limitations which it is well recognized that a patentee may place on a license to another in the exercise of his rights under a patent. These will be briefly referred to.

I. Royalty. In general, the patentee may fix any terms of royalty he chooses.

2. Sale price. The patentee may grant a license to manufacture and to sell only at prices fixed by the patentee. ${ }^{25}$ When there are a number of licensees, the patentee may fix uniform prices for the various licenses as a condition of the waiver of his exclusive rights.

Such price fixing must be based, however, on the belief that the patent is valid, and a patent must not be used as a mere subterfuge for price fixing. Nor can the licensees use the patent as an excuse for agreeing among themselves to fix prices.

Also, so long as the patentee, who himself manufactures, retains title to the articles which he manufactures under the patent, his patent rights permit him to fix the price at which his distributors (del credere agents) may sell the article. There is no violation of the antitrust laws in fixing the price at which such agents shall sell to the consumer.

1"Id. at 92. $\quad 23305$ U. S. I24 (1938). 21 Id. at 127.

${ }^{26}$ United States v. General Electric Co., 272 U. S. 476 (x926). For extremely important recent holdings on this subject, see the Line Material and the Gypsum cases, infra. 
3. Quantity. The patentee may, in the license, limit the quantity or the percentage of the total output to be manufactured by the licensee.

4. Territorial licenses. The statutes provide that the patentee may assign his rights under his patent for a specified territory. ${ }^{26}$ Likewise, he may grant licenses, exclusive or non-exclusive, for a given territory. He may even limit the use to the licensee's own factory or place of business.

5. Number of licensees. The patentee can determine for himself the persons, one or more, whom he will license. The mere fact that it may be his general policy to issue licenses does not obligate him to grant licenses to all comers. The patent owner may license or refuse to license as he sees fit.

6. Field of use or purpose for which the license is granted. The patentee may grant licenses restricted to a particular field or fields of use, or for some particular purpose or purposes.

These are the more general forms of limited or restricted licenses which the courts recognize as valid by virtue of rights accruing to the patentee from the grant of his patent.

\section{Restrictions Outside the Scope of a Patent}

Having pointed out some of the kinds of restricted or limited licenses that are within the rights granted by a patent, I shall next consider some of the restrictions which the courts have held to be outside the scope of a patent.

In the first place, the Supreme Court has uniformly held that, after the unrestricted sale of a patented article by the patentee, or by a licensee having unqualified rights to make the sale, the article is freed from the monopoly of the patent and an agreement with respect to subsequent control cannot be justified by the fact that the article is covered by a patent. ${ }^{27}$ In other words, the article, after such sale, moves outside the patent monopoly. In applying the old doctrine that, after sale of a patented article, the patent on it can no longer control the use of that article, the Supreme Court has gone so far as to state that such is the case irrespective of the fact that the use to be made of the article sold is itself covered by still another patent. Once having sold an article for its intended use, the patent owner has lost control of further use of such article. ${ }^{28}$

There are certain restrictive agreements, properly so-called, which do not find justification by virtue of patent ownership. Among these may be mentioned: ( $\mathrm{r}$ ) Resale price maintenance; (2) agreement of a patent owner not to use his own invention, or to restrict his own use, in the absence of a complete transfer of his patent rights to another; (3) agreement to use only supplies furnished by the patent owner in connection with an article sold or leased by the patentee; and (4) agree-

${ }^{28}$ Rev. STAT. $\$ 4898$ (1875), 35 U. S. C. $\$ 47$ (1940).

${ }^{27}$ Dr. Miles Medical Co. v. John D. Park \& Sons Co., 220 U. S. 373 (I9II).

${ }^{38}$ See Ethyl Gasoline Corp. v. United States and United States v. Univis Lens $C_{0}$., infra. 
ments in general not to deal in the goods, wares, or merchandise of a competitor.

Such agreements, as well as methods of conducting business, outside the patent monopoly should be scanned with care to determine whether they are likely to result in unreasonably lessening competition or in restraint of trade in interstate or foreign commerce, and thereby violate the antitrust laws. Also, in general, care should be taken that the patent is not being used contrary to the public interest. The courts have even gone so far as to consider attempts to use the patent for such purposes as a misuse thereof, even though there is no violation of the antitrust laws. Recent decisions of the Supreme Court are to the effect that in such cases the patentee will be refused relief against infringement.

In short, it may be said the recent trend is to apply the antitrust laws most stringently, or even to consider with care whether, aside from violation of the antitrust laws, a use of the patent against the public interest is involved.29

In general, it may be said that whether patent agreements involving "restrictions" run afoul of the antitrust laws depends upon the nature of the agreements, and primarily upon whether the restraints are within the four corners of the right to restrain granted by the patent, or are restraints resulting from agreements extending beyond the patent monopoly, even though dealing incidentally with the patent property as a subject of contract.

\section{Aggregation of Patents under a Single Control}

Many of the decisions which have been referred to have dealt with instances in which a number of patents were brought under a single control either by crosslicensing or by pooling. In this connection, two questions arise: (r) To what extent may "non-competing" or "supplementary" patents be acquired legally by purchase or consolidation to strengthen a commercial position? and (2) the same question where the patents are "competing" patents-that is, patents representing alternative products or methods. An instance of the consolidation of "non-competing" or "supplementary" patents is found in United States $v$. Winslow, in which it was held that the union in one corporation of three different companies, each manufacturing under a different "non-competing" group of patented machines, collectively used for making shoes, is not forbidden by the Sherman Act, although a large percentage of the shoe-machinery business may thus be put in a single hand. ${ }^{31}$

The second question, concerning the right by purchase or merger to bring under the same control "competing" patents previously held by adverse interests, does not seem to have been before the Supreme Court as often as might be expected. Of course, such combinations would be subject to careful scrutiny by the courts to ascertain the reasonableness of any restraint which might arise. The Gasoline

${ }^{20}$ See Morton Salt Co. v. G. S. Suppiger Co. and B. B. Chemical Co. v. Ellis, infra.

${ }^{20} 227$ U. S. 202 (I913).

${ }^{31}$ For an opinion with substantially the same effect but by a divided court, see the first Shoe Machinery case, United States v. United Shoe Machinery Co., 247 U. S. 32 (19r8). 
Cracking case ${ }^{32}$ presents a variety of interesting questions on this subject worthy of detailed consideration. In that case there were four main defendants, each owning its own patents for processes used in gasoline cracking. There were forty-six secondary defendants who were manufacturing under licenses from the main defendants. In all, some seventy-nine contracts had been entered into.

No fundamental patent was involved. Nevertheless, litigation had arisen and still more was threatened. As a result, the parties entered into the agreement complained of. The agreement provided that each main defendant might secure licenses under the patents of the others, together with the right to issue sub-licenses. The contract also provided for fixed royalties, all of which were to be divided according to a fixed plan.

The Court in this case found that there was no unreasonable restriction of competition; that the amount of gasoline produced by the parties to the contract was only about 26 per cent of the total gasoline production; and that there was no proof that the defendants could, by reason of their contract, fix the market price of gasoline.

In short, the Court found that no additional monopoly of any kind and no restraint of interstate commerce had been effected by means of the contract.

The subject of accumulating patents by purchase, the pooling of patents, crosslicensing agreements, acquisition of improvement patents, etc., cannot be gone into fully within the limits of the present paper. ${ }^{33}$ It should be borne in mind, however, as has been stated, that the monopoly granted by patents does not exempt the patentee from the prohibitions of the antitrust laws. However, agreements reasonably necessary to protect the patent owner in the enjoyment of his patent rights are not in conflict with the antitrust laws. The mere grant of licenses-i.e., the waiver of exclusion-does not lessen competition or restrain trade, but quite the contrary, and is not in conflict with the antitrust laws. Patents, however, may not be used as a subterfuge for maintaining a monopolistic combination. This is well set forth in Blount Manufacturing Company v. Yale \& Towne Manufacturing Company, wherein the Court stated:

It seems self-evident that a contract which is only coextensive with the monopoly conferred by letters patent, and which creates no additional restraint of trade or monopoly, does not conflict with the Sherman Act. ... A contract whereby the manufacturers of two independent patented inventions agree not to compete in the same commercial field deprives the public of the benefits of competition, and creates a restraint of trade which results, not from the granting. of letters patent, but from agreement. ${ }^{34}$

\section{Recent Supreme Court Decisions}

I have discussed the time-honored decisions of the Supreme Court with reference to the scope of the patent monopoly. I have mentioned the divergent views that the

${ }^{32}$ Standard Oil Co. v. United States, 283 U. S. 163 (193I).

${ }^{33}$ For a decision dealing with the acquisition of improvement patents and possible dangers involved, see Transparent-Wrap Machine Corp. v. Stokes \& Smith Co., infra.

ss 166 Fed. 555, 557 (D. Mass. 1909). 
Antitrust Division of the Department of Justice has urged. I shall now refer to the more recent decisions of the Supreme Court in a chronological, case-by-case method to determine to what extent the Supreme Court has reaffirmed previous holdings and to what extent, if at all, it has expressed departures from those holdings. A study of these decisions discloses that there has been no departure from the established view regarding the rights which a patentee acquires; that the courts will deal harshly with "misuse" of patents even where there is no violation of antitrust laws, having thrown aside precedents; and that decrees may be expected which in effect wholly or partially confiscate patent property.

The General Talking Pictures case. ${ }^{35}$ This case reaffirms the right of a patentee to grant restricted licenses, and holds that, where a license is restricted to a particular field or purpose of use, one who knowing the fact purchases the apparatus from the licensee and uses it in other fields is an infringer. On this latter point there was a dissenting opinion.

Ethyl Gasoline Corporation v. United States. ${ }^{38}$ In this case the rights of a patentee and the limits of those rights are stated at some length. Ethyl, after the sale of its product, was attempting through other patents to control jobbers' pricesin effect trying to control resale prices. The Court stated:

[The situation] is one in which appellant has established the marketing of the patented fuel in vast amounts on a nationwide scale through the $x \mathrm{r}, 000$ jobbers and at the same time, by the leverage of its licensing contracts resting on the fulcrum of its patents, it has built up a combination capable of use, and actually used, as a means of controlling jobbers' prices and suppressing competition among them. ${ }^{37}$

Morton Salt Company v. G. S. Suppiger Company. ${ }^{38}$ This was a suit brought for an injunction and an accounting for the infringement of a patent on a machine for depositing salt tablets.

The Court found that the patentee was making use of its patent monopoly to restrain competition in the marketing of unpatented articles (salt tablets) for use with the patented machine, and was thus creating a limited monopoly not within that created by the patent. The Court stated:

It is a principle of general application that courts, and especially courts of equity, may appropriately withhold their aid where the plaintiff is using the right asserted contrary to the public interest.

Equity may rightly withhold its assistance from such a use of the patent by declining to entertain a suit for infringement, and should do so at least until it is made to appear that the improper practice has been abandoned and that the consequences of the misuse of the patent have been dissipated. ${ }^{39}$

The Court found it unnecessary to decide whether the Clayton Act had been violated.

${ }^{38} 305$ U. S. 124 (1938).

${ }^{27}$ Id. at 457 .

${ }^{88} 309$ U. S. 436 (1940).

3o 1d. at 492, 493 .

${ }^{28} 3$ I U. S. 488 (r942). 
B. B. Chemical Company v. Ellis. ${ }^{40}$ This was a companion case to the Morton Salt Company case, and the decision of the Court was to the same effect, stating:

It will be appropriate to consider petitioner's right to relief when it is able to show that it has fully abandoned its present method of restraining competition in the sale of unpatented articles and that the consequences of that practice have been fully dissipated.11

United States v. Univis Lens Company. ${ }^{42}$ This case is similar in some respects to the Ethyl case. It holds that one who sells a patented product in its uncompleted form, for further development, cannot rely on other patents relating to subsequent treatment to control prices. He has parted with his control of the product. He has parted with any monopoly that patents can confer.

United States v. Masonite Corporation. ${ }^{43}$ In this case a number of corporations were each engaged either in manufacturing or in selling building materials. All maintained selling organizations and to a large extent competed in the same markets. Some had competing patents, others did not. Under the agreements, Masonite designated the other parties as "agents" and appointed them to sell Masonite products. Masonite fixed the minimum selling prices of such "agents." Furthermore, Masonite agreed to adhere to the prices and conditions which it fixed for those agents, thus binding itself to a condition outside the scope of its patents, since the patent gives the patent owner no right to agree to exclude himself. The Court found that there was no genuine agency involved, and hence the case did not come within the ruling of the General Electric case. ${ }^{44}$ The holding was to the effect that in turning over its products to its so-called agents, the Masonite company parted with its right to any further control; that when the patented product "passes to the hands of the purchaser, it is no longer within the limits of the monopoly"; that he then has, so far as the Sherman Act is concerned, no greater right to price maintenance than the owner of the unpatented commodity would have. The Court went to some length in reasserting the scope and limits of the patent monopoly.

Sola Electric Company v. Jefferson Electric Company. ${ }^{45}$ This case involved a patent license contract which provided that the licensee, on sales of licensed transformers throughout the United States, should conform to the prices fixed by licensor for the sale of competing patented articles by other licensees and by the licensor. The Court stated:

Such a restriction on the price of articles entering interstate commerce is a violation of the Sherman Act save only as it is within the protection of a lawfully granted patent monopoly...

and therefore,

... petitioner may assert the illegality of the price-fixing agreement and may offer any
${ }^{10} 314$ U. S. 495 (1942).
12316 U. S. 24 I (1942).
11 Id. at 498 .
13 316 U. S. 265 (1942).
"United States v. General Electric Co., 272 U. S. 476 (I926).
${ }^{45} 317$ U. S. 173 (I942). 
competent evidence to establish its illegality, including proof of the invalidity of the patent. ${ }^{48}$

The Glass Industry case. ${ }^{47}$ The Court went to some length in reaffirming old principles and was unanimous in finding violation of the Sherman Act. Not even in the dissenting opinions was any disagreement expressed with respect to the fundamental concepts of the patent system. Only with respect to the nature of the decree was there dissent. The dissents refer to "a . . . misconception, that men who have misused their property, and acquired much of it, by violating the Sherman Act, are free for the future to continue using it as are other owners who have committed no such offense." 48

Precision Instrument Manufacturing Company v. Automotive Maintenance Machinery Company. "The guiding doctrine in this case," the Court stated, "is the equitable maxim that "he who comes into equity must come with clean hands." Continuing, the Court said:

A patent by its very nature is affected with a public interest. As recognized by the Constitution, it is a special privilege designed to serve the public purpose of promoting the "Progress of Science and Useful Arts." At the same time, a patent is an exception to the general rule against monopolies and to the right to access to a free and open market. 0

Edward Katzinger Company v. Chicago Metallic Manufacturing Company ${ }^{51}$ and MacGregor v. Westinghouse Electric \& Manufacturing Company. ${ }^{52}$ The question here is whether the defendant, in a suit to recover royalties only under a patent license agreement containing price-fixing provisions, can challenge the validity of the patent despite a covenant in the license contract that he would not do so.

The Court held that it can, with four of the justices in a strong dissent.

Transparent-Wrap Machine Corporation v. Stokes \& Smith Company.53 The provision of the agreement around which the controversy turned was a covenant to assign improvement patents. With respect thereto, the Court stated:

An improvement patent, like the basic patent to which it relates, is a legalized monopoly for a limited period. The law permits both to be bought and sold. One who uses one patent to acquire another is not extending his patent monopoly to articles governed by the general law and as respects which neither monopolies nor restraints of trade are sanctioned. He is indeed using one legalized monopoly to acquire another legalized monopoly.

It is true that for some purposes the owner of a patent is under disabilities with which owners of other property are not burdened. Thus where the use of unpatented materials is tied to the use of a patent, a court will not lend its aid to enforce the agreement though control of the unpatented article falls short of a prohibited restraint of trade or monopoly. Morton Salt Co. v. Suppiger Co., supra. There is a suggestion that the same course

${ }^{10} \mathrm{Id}$. at $\mathrm{I75}, \mathrm{I77}$.

${ }^{18} \mathrm{Id}$. at $440,44 \mathrm{I}$.

${ }^{81} 329$ U. S. 394 (1947).
"Hartford-Empire Co. v. United States, 323 U. S. 386 (x945).

624 U. S. 806 (1945). $\quad{ }^{50}$ Id. at 814, 8I6.

${ }^{52} 329$ U. S. 402 (1947). $\quad$ ss 329 U. S. 637 (1947). 
should be followed in this case since the tendency of the practice we have here would be in the direction of concentration of economic power that might run counter to the policy of the anti-trust laws. The difficulty is that Congress has not made illegal the acquisition of improvement patents by the owner of a basic patent. The assignment of patents is indeed sanctioned. And, as we have said, there is no difference in the policy of the assignment statute whatever consideration may be used to purchase the improvement patents. And apart from violations of the anti-trust laws to which we will shortly advert, the end result is the same whether the owner of a basic patent uses a license to obtain improvement patents or uses the wealth which he accumulates by exploiting his basic patent for that purpose. In sum, a patent license may not be used coercively to exact a condition contrary to public policy. But what falls within the terms of the assignment statute is plainly not per se against the public interest.

We are quite aware of the possibilities of abuse in the practice of licensing a patent on condition that the licensee assign all improvement patents to the licensor. Conceivably the device could be employed with the purpose or effect of violating the anti-trust laws. $\mathrm{He}$ who acquires two patents acquires a double monopoly. As patents are added to patents a whole industry may be regimented. The owner of a basic patent might thus perpetuate his control over an industry long after the basic patent expired. Competitors might be eliminated and an industrial monopoly perfected and maintained. Through the use of patent pools or multiple licensing agreements the fruits of invention of an entire industry might be systematically funneled into the hands of the original patentec. See United Shoe Machinery Co. v. La Chapelle, 212 Mass. 467, 99 N. E. 289.

Congress, however, has made no specific prohibition against conditioning a patent license on the assignment by the licensee of improvement patents. But that does not mean that the practice we have here has immunity under the anti-trust laws. Indeed, the recent case of Hartford-Empire Co. v. United States, 323 U. S. 386 . . , 324 U. S. 570 . . . , dramatically illustrates how the use of a condition or covenant in a patent license that the licensee will assign improvement patents may give rise to violations of the anti-trust laws.

We only hold that the inclusion in the license of the condition requiring the licensee to assign improvement patents is not per se illegal and unenforceable. ${ }^{54}$

There were dissenting opinions, in 'one of which it is stated: “. . . the Court's decision in this case unduly enlarges the scope of patent monopolies and is inconsistent with the philosophy enunciated in Mercoid Corporation v. Mid-Continent Company, 320 U. S. 661 ... and similar cases."

United States $v$. National Lead Company. ${ }^{56}$ This case presents a so-called "international cartel" dating back to r920, at which time the National Lead Company entered into an agreement with foreign companies by which the world markets were divided, even in some cases where there were no patents in certain of those countries. Later, in I933, the du Pont Company, a potential competitor, entered to a greater or lesser extent into the combination.

Whether or not the original agreement by the National Lead Company was a

st Id. at $644,645,646,647,648$.

${ }^{55} 1 d$. at 648 .

${ }^{68} 67$ Sup. Ct. 1634 (U. S. 1947). 
violation of the antitrust law was the first issue presented. The second issue was with respect to the later participation of the du Pont Company in such combinations in I933, the question being whether the latter company had succeeded in avoiding not only the form but also the substance of the transgression.

Still a third issue was whether the contract between National Lead and du Pont was offensive to the antitrust laws apart from the relation of that contract and the parties thereto to foreign producers.

The validity of none of the hundreds of patents involved had been litigated.

The Court laid stress on the fact that a new industry had been created for titanium products and that this new industry had been dominated because of the agreements entered into. On the question of violation of the anitrust laws there was no difference of opinion; the Court found that there had been a violation thereof. Referring to the special conditions in the case, the Supreme Court found:

These findings disclose the special conditions which confronted the District Court in framing its decree. They disclose a vigorous, comparatively young, but comparatively large, world-wide industry in which two great companies, National Lead and du Pont, now control approximately $90 \%$ of the domestic production in substantially equal shares. The balance of that production is in the hands of two smaller companies. Each of these is affiliated with larger organizations, not parties to this case. The findings show vigorous and apparently profitable competition on the part of each of the four producers, including an intimation that the smaller companies are gaining ground rather than losing it. Keen competition has existed both before and after the elimination, by the 1933 agreement and understanding, of certain patent advantages from among the weapons of competition. ${ }^{57}$

There was no difference of opinion regarding the question of violation of the antitrust laws. There was, however, a dissenting opinion with respect to the proper remedy which should be applied in order to grant effective relief.

The decision of the Court, a lengthy one, is of importance as a pronouncement upon international agreements, a subject upon which there was little prior authoritative statement.

International Salt Company, Inc. v. United States. ${ }^{58}$ The Government brought this civil action to enjoin the International Salt Company from carrying out the provisions of its leases of its patented machines to the effect that the lessee would use therein International's salt products, which were unpatented goods.

The Court stated:

Under the law, agreements are forbidden which "tend to create a monopoly," and it is immaterial that the tendency is a creeping one rather than one that proceeds at full gallop; nor does the law await arrival at the goal before condemning the direction of the movement.

Of course a lessor may impose on a lessee reasonable restrictions designed in good faith to minimize maintenance burdens and to assure satisfactory operations. . . . Rules

${ }^{87} \mathrm{Id}$. at 1647 .

${ }^{68} 68$ Sup. Ct. 12 (U. S. I947). 
for use of leased machinery must not be disguised restraints of free competition, though they may set reasonable standards which all suppliers must meet. ${ }^{50}$

On this main issue there was no dissent, though on the matter of the remedy that should be applied there was a dissenting opinion in which is the statement: "Agreeing wholeheartedly with the Court's opinion on the main issue, I am left unpersuaded. . ." ${ }^{\prime 0}$ with respect to the nature of the decree directed to be entered.

United States v.U.S. Gypsum Company. ${ }^{01}$. This case involved license agreements in which a minimum sale price was provided for.

The Court was unanimous in holding that the instant case presented a violation of the antitrust laws, and distinguished it from the decision of the Court in the General Electric case.

The decision is a voluminous one, and the principal question involved may be gathered from the following quotation from the opinion:

The General Electric case affords no cloak for the course of conduct revealed in the voluminous record in this case. That case gives no support for a patentee, acting in concert with all members of an industry, to issue substantially identical licenses to all members of the industry under the terms of which the industry is completely regimented, the production of competitive unpatented products suppressed, a class of distributors squeezed out, and prices on unpatented products stabilized. We apply the "rule of reason" of Standard Oil Co. of New Jersey v. United States, 22 I U. S. I, . . . to efforts to monopolize through patents as well as in non-patent fields. Even in the absence of the specific abuses in this case, which fall within the traditional prohibitions of the Sherman Act, it would be sufficient to show that the defendants, constituting all former competitors in an entire industry, had acted in concert to restrain commerce in an entire industry under patent licenses in order to organize the industry and stabilize prices. That conclusion follows despite the assumed legality of each separate patent license, for it is familiar doctrine that lawful acts may become unlawful when taken in concert. Such concerted action is an effective deterrent to competition; ... . The rewards which flow to the patentee and his licensees from the suppression of competition through the regulation of an industry are not reasonably and normally adapted to secure pecuniary reward for the patentee's monopoly. ${ }^{62}$

One feature of the case not necessary to the decision is of interest because the Court stated that in an antitrust suit the Government should have the right to challenge the validity of patents involved. From this view Mr. Justice Frankfurter, while concurring in the main decision, expressly dissented, stating:

In Part II of the opinion the Court confessedly deals with an issue that "need not be decided to dispose of this case." Deliberate dicta, I had supposed, should be deliberately avoided. Especially should we avoid passing gratuitously on an important issue of public law where due consideration of it has been crowded out by complicated and elaborate issues that have to be decided. Accordingly, I join in the Court's opinion, except Part II. ${ }^{03}$

United States $v$. Line Material Company. ${ }^{64}$ The opinion of the Supreme Court in this case was rendered by Mr. Justice Reed. The Court found that the respondent

\footnotetext{
${ }^{80} 1 d$. at 15,16 .

${ }^{02} 68$ Sup. Ct. 525 (U. S. 1948).

${ }^{03}$ Id. at 548 .
}

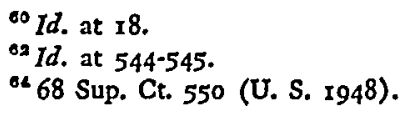


had been guilty of violating the antitrust laws by sales price restrictions in license contracts.

The question for decision was whether, in the light of the prohibition of the Sherman Act, two or more patentees in the same patent field may legally combine their patent monopolies so as to control the sale price of the patented devices manufactured under both groups of patents.

The two patents involved were a Lemmon patent issued to the Southern States Equipment Corporation and a Schultz patent assigned to the Line Material Company. As a result of an interference in the Patent Office, broad claims were issued in the Lemmon patent and narrower claims in the Schultz patent. The Court recognized the fact that "only when both patents could be lawfully used by a single maker could the public or the patentees obtain the full benefit of the efficiency and economy of the inventions." with a provision by which it could issue licenses to others, Line agreeing to sell equipment covered by the Southern patent at prices not less than those fixed by Southern. Southern made the same agreement for equipment covered solely by the Line patent. Thereafter, Line issued a number of licenses to others containing the sales price limitation feature.

The Government attacked the rationale of the General Electric case and urged that is be overruled or differentiated. Mr. Justice Reed stated that he himself accepted the rule in the General Electric case, but pointed out that the instant case could not be decided on that basis, since on the question of the right of a patentee to fix sale price restrictions in a license, the Court was equally divided, four of the justices upholding the opinion in the General Electric case and four others, though concurring in the view that in the case in question there was a violation of the antitrust laws, taking the further view that the General Electric case should be overruled. In the Court's opinion it is stated:

Where a patentee undertakes to exploit his patent by price fixing through agreements with anyone, he must give consideration to the limitations of the Sherman Act on such action. The patent statutes give an exclusive right to the patentee to make, use, and vend and to assign any interest in this monopoly to others. The General Electric case construes that as giving a right to a patentee to license another to make and vend at a fixed price. There is no suggestion in the patent statutes of authority to combine with other patent owners to fix prices on articles covered by the respective patents. As the Sherman Act prohibits agreements to fix prices, any arrangement between patentees runs afoul of that prohibition and is outside the patent monopoly. ${ }^{66}$

In short, the Court held that the combination of different patentees for the purpose of fixing the sale prices was unlawful under the Sherman Act and that others who subsequently enter into license agreements with price-fixing provisions with knowledge of the contract are equally subject to the prohibition of the antitrust laws.

${ }^{\circ} \mathrm{Id}$. at 553 .

${ }^{\circ 1} I d$. at 563 . 
Mr. Justice Douglas, with whom Mr. Justice Black, Mr. Justice Murphy, and Mr. Justice Rutledge joined, while concurring in the Court's opinion, stated flatly, "I would be rid of United States v. General Electric Co.", and in his concurring opinion he gives his reasons for that position. ${ }^{67}$

Mr. Justice Burton, with whom the Chief Justice and Mr. Justice Frankfurter concurred, wrote a dissenting opinion as to the violation of the antitrust laws, and at great length set forth the reasons why the decision in the General Electric case should apply to the instant case.

Thus it appears that on the question of overruling the opinion in the General Electric case the Court was divided four to four, one of the justices taking no part in the consideration of the case.

${ }^{67}$ Id. at 565 . 